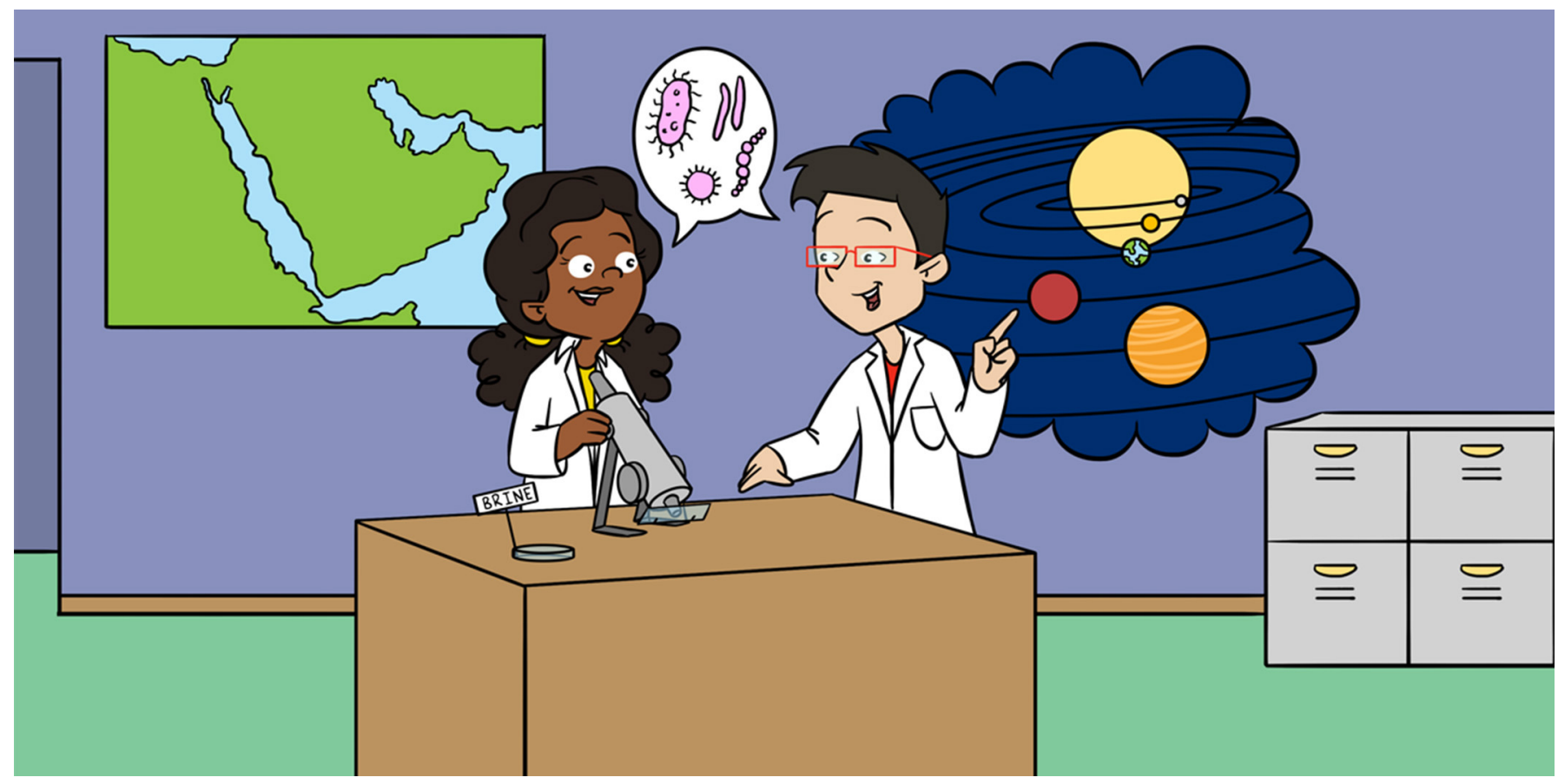

\title{
OUT OF THIS WORLD: FROM THE BOTTOM OF THE RED SEA TO THE RED PLANET
}

\section{André Antunes *}

State Key Laboratory of Lunar and Planetary Sciences, Macau University of Science and Technology, Macau, China

\section{YOUNG REVIEWERS:}

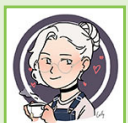

CHLOE

AGE: 15

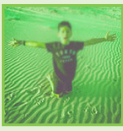

FABIÁN

AGE: 12

(2) NAGA

AGE: 15

SAGE

AGE: 11

XENIA

AGE: 15
The deep-sea brines of the Red Sea are some of the most extreme environments on Earth. They have high salinity, high temperature, high pressure, and no oxygen. Despite such harsh conditions, several organisms still live in these brines. The study of deep-sea brines and their inhabitants has several advantages. In addition to finding several new species, deep-sea brines are a source of useful new molecules produced by these organisms. These new molecules could be used for healing people or even cleaning up our planet. The deep-sea brines could also aid us in looking for extraterrestrial life. These brines are also helpful for planning future space missions due to similarities with conditions on other planets and moons.

\section{WHAT ARE DEEP-SEA BRINES AND HOW ARE THEY FORMED?}

The Red Sea is unique! It is growing by a few millimeters every year. In a few million years it will become a full-fledged ocean, like the Atlantic or the Pacific. The Red Sea is growing because of the separation of the 
TECTONIC PLATES

Large pieces of the Earth's crust shifting or moving around, sometimes. Bumping into one another or moving away from each other.
MOLECULAR

\section{BIOLOGY}

The study of living things based on their molecules (such as DNA or proteins) rather than the whole organism.
Arabian and African tectonic plates. The gap left between these plates, which is in the middle of the Red Sea, is filled by patches of new oceanic crust. As oceanic crust is denser than continental crust, these patches create deep spots called deeps (a deeper area or hole in the seafloor) and are scattered across the mid-section of the Red Sea [1].

The movement of the earth's crust happening under the Red Sea exposes massive buried deposits of salt. The deposits were formed from the drying of a prehistoric ocean that existed in this area. The seawater dissolves some of the salt and becomes a brine, which is very salty water. Salinity, which is the word for the measure of saltiness, can increase by up to 7-fold in the brines. These brines are heavy, so they concentrate at the bottom of the sea and accumulate in the deeps formed by the oceanic crust. The high density of the brines and their sheltered location in the deeps prevents them from mixing with seawater. Because of this, deep-sea brines are very stable and look like underwater lakes. They even have waves across their surfaces and beaches at their rims. In addition to higher salinity, brines have other differences from seawater: they have no oxygen and have higher amounts of metals and other elements. Brines also have a lower $\mathrm{pH}$ than seawater and a higher temperature.

\section{AN ACCIDENTAL DISCOVERY}

Deep-sea brines were accidentally discovered in the 1950s, when researchers collected a deep-sea water sample that was much saltier and warmer than usual. Follow-up surveys discovered at least 25 different deep-sea brines scattered across the center of the Red Sea (Figure 1). Each brine is unique due to differences in local geology, age, and differences in heating from the earth's crust [1]. Atlantis II is the biggest (over $80 \mathrm{~km}^{2}$ ), the hottest $\left(68.2^{\circ} \mathrm{C}\right.$ ), and one of the oldest brines. On the other extreme, Kebrit is the smallest $\left(2.5 \mathrm{~km}^{2}\right)$, the coldest $\left(23.3^{\circ} \mathrm{C}\right)$, and one of the youngest brines. Kebrit is also rich in sulfur and is very smelly-"kebrit" is the Arabic word for sulfur, which smells like rotten eggs.

\section{WHAT LIVES IN DEEP-SEA BRINES?}

For a long time, researchers thought that conditions in the deep-sea brines were too extreme for life. They assumed that no organisms would be able to survive there. However, technical advances, particularly in molecular biology, allowed us to explore the brines in more detail and revealed thriving communities. Studies have found microbes, animals, and even viruses in the brines [1]. These studies have discovered many new species, some unlike any other on our planet (Figure 2). These organisms are so unique that some 
Figure 1

Map of the Red Sea showing the locations of the main deep-sea brines. The red lines on the map show regions with different stages of tectonic activity and development of the brines.

\section{EXTREME}

\section{ENVIRONMENT}

Place with conditions that are very different from the ones that we are able to live in. Some examples include high or low temperatures, acidic or alkaline conditions, high pressure, or high salinity

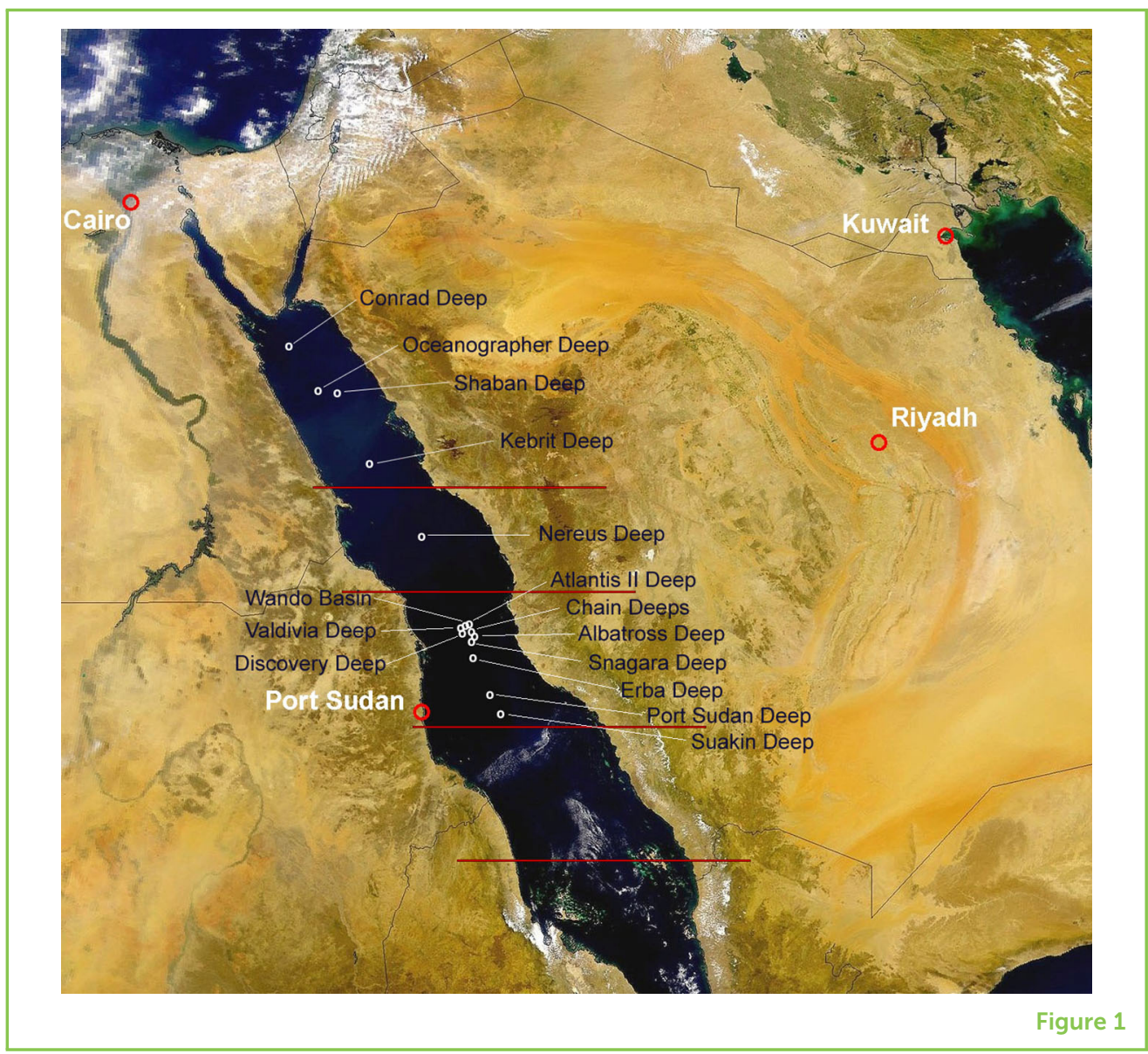

of these findings are equivalent to finding the very first carnivores or vertebrates!

\section{WHY SHOULD WE STUDY BRINE MICROBES?}

There are more microbes in our oceans than stars in the universe [4]! Yet, more than $99 \%$ of the total microbial diversity remains unexplored. The discovery of new microbes and the study of their abilities are always exciting. We keep uncovering new ways that microbes impact our planet and all life on Earth.

Because microbes can grow in such unique conditions, those from extreme environments are often a source of valuable new molecules. Their range of applications is so wide that these molecules are seen as the future solutions on how to feed, fuel, and heal the world [5]. Microbes from the brines of the Red Sea also seem to be very useful. Some show anti-cancer activity, while others seem capable of producing bioplastics (biologically-produced plastics that do not rely on the use of oil), cleaning up oil spills, or even capturing carbon dioxide [6]. Scientists think that some of these microbes could be used to restore contaminated sites or even to prevent climate change! Studying extreme environments like the deep-sea brines also helps 
Figure 2

The deep-sea brines contain many exotic new species.

Haloplasma contractile is a newly discovered bacterium that can (A) contract and (B) relax its cells. (C)

Salinisphaera

shabanensis is another new bacterium found in deep-sea brine that is able to grow well in very different salinities. Both microbes were observed with electron microscopy, a powerful technique in which a microscope uses electron beams instead of light to create an image (Image credits: A,B: Copyright (C) American Society for Microbiology [2]; C: Copyright (C) Springer [3]).
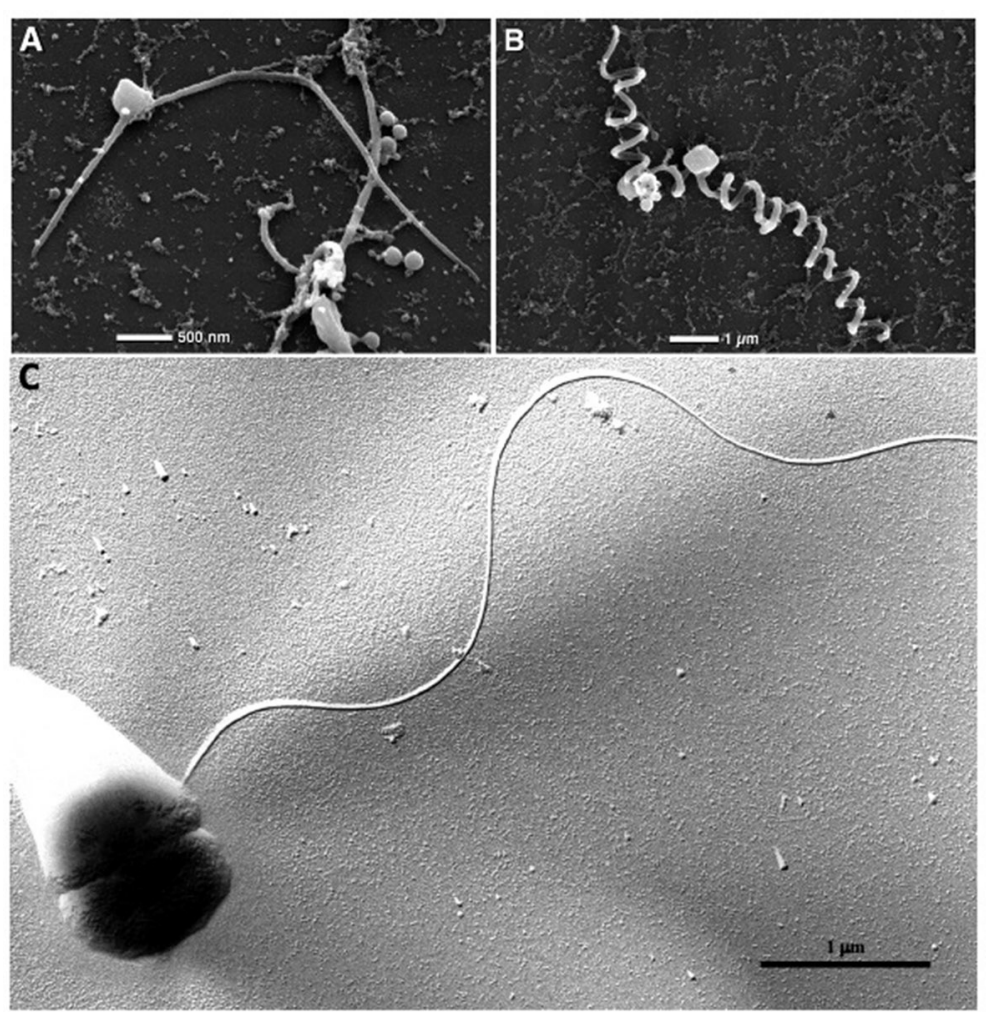

Figure 2

us to test hypotheses about the physical and chemical limits for the existence of life. These findings could aid researchers looking for life elsewhere in the universe.

\section{TO INFINITY AND BEYOND!}

Astrobiology is a new science combining many different fields, including biology, geology, chemistry, and planetary sciences. Its main goal is the search for life outside our planet. Currently Mars, Jupiter's moon Europa, and Saturn's moon Enceladus are the top candidates when looking for extraterrestrial life (Figure 3). The extreme conditions that exist in those places are not very different from some extreme places on Earth [7]. The presence of water, which is essential for life, is very likely on Mars, Europa, and Enceladus, and that water probably has high salinity like that found in the brines of the Red Sea. Astrobiology also studies the limits of life-how extreme do conditions have to be before life cannot possibly exist? This goal can be aided by the exploration of extreme environments on Earth. Findings from these extreme terrestrial environments can help us prepare for future space missions looking for life.

The deep-sea brines of the Red Sea are important astrobiological sites [7]. They resemble the predicted conditions at the bottom of the oceans of Europa and Enceladus. They are a source of microbes that 
Figure 3

The current main targets for astrobiological research on our solar system are the moons Enceladus (top left) and Europa (bottom left), and the planet Mars (right). Image credits NASA
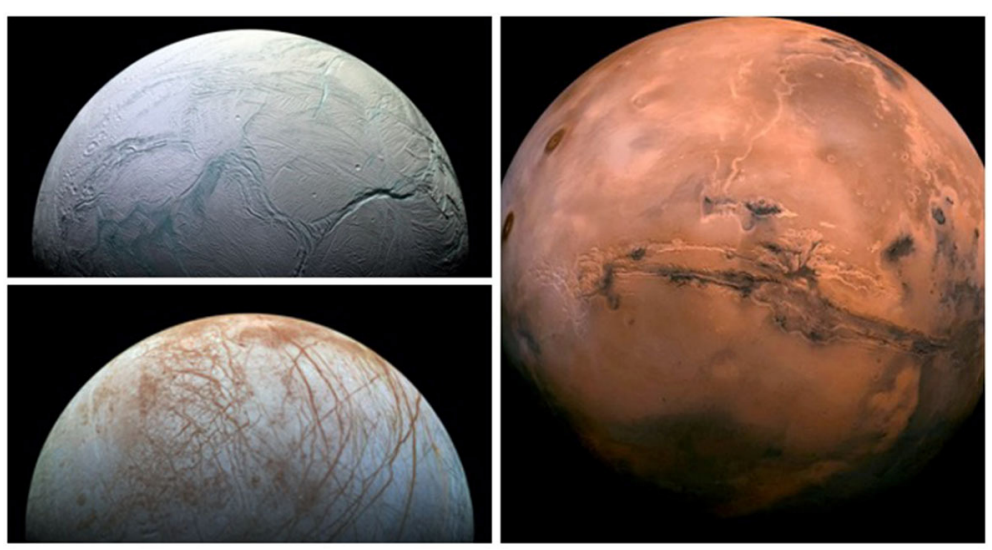

Figure 3

have been picked as priority targets for astrobiological studies. Several of these microbes are being tested in simulation chambers and in balloon trips to the upper layers of earth's atmosphere. A selected few will even be sent to the International Space Station for space-exposure experiments. These studies will allow us to see if these microbes can survive and grow when exposed to space or to conditions found on Mars.

\section{CONCLUSION}

The deep-sea brines of the Red Sea are amazing, extreme environments unlike any other on our planet. These brines are important for many different fields. They are a source of exotic new microbes, new applications, and are also useful in the search for extraterrestrial life. We have only just started to explore deep-sea brines and their inhabitants and can expect many new findings in the near future.

\section{REFERENCES}

1. Antunes, A., Ngugi, D. K., and Stingl, U. 2011. Microbiology of the Red Sea (and other) deep-sea anoxic brine lakes. Environ. Microbiol. Rep. 3:416-33. doi: 10.1111/j.1758-2229.2011.00264.x

2. Antunes, A., Rainey, F. A., Wanner, G., Taborda, M., Pätzold, J., Nobre, M. F., et al. 2008. A new lineage of halophilic, wall-less, contractile bacteria from a brine-filled deep of the Red Sea. J. Bacteriol. 190:3580-7. doi: 10.1128/jb.0 1860-07

3. Antunes, A., Eder, W., Fareleira, P., Santos, H., and Huber, R. 2003. Salinisphaera shabanensis gen. nov., sp. nov., a novel, moderately halophilic bacterium from the brine-seawater interface of the Shaban Deep, Red Sea. Extremophiles 7:29-34. doi: 10.1007/s00792-002-0292-5

4. Antunes, A., Stackebrandt, E., and Lima, N. 2016. Fueling the bio-economy: European culture collections and microbiology education and training. Trends 
Microbiol. 24:77-9. doi: 10.1016/j.tim.2015.11.010

5. Antunes, A., Simões, M. F., Grötzinger, S. W., Eppinger, J., Bragança, J., and Bajic, V. B. 2017. "Bioprospecting archaea: focus on extreme halophiles," in Bioprospecting. Topics in Biodiversity and Conservation, Vol. 16, eds R. Paterson and N. Lima (Cham: Springer). p. 81-112. doi: 10.1007/978-3-319-4 7935-4_5

6. Varrella, S., Tangherlini, M., and Corinaldesi, C. 2020. Deep hypersaline anoxic basins as untapped reservoir of polyextremophilic prokaryotes of biotechnological interest. Mar. Drugs 18:91. doi: 10.3390/md18020091

7. Antunes, A., Olsson-Francis, K., and McGenity, T. J. 2020. Exploring deep-sea brines as potential terrestrial analogues of oceans in the icy moons of the outer solar system. Curr. Issues Mol. Biol. 38:123. doi: 10.21775/cimb.038.123

SUBMITTED: 26 March 2020; ACCEPTED: 16 September 2020;

PUBLISHED ONLINE: 27 October 2020.

EDITED BY: Rúben Martins Costa, King Abdullah University of Science and Technology, Saudi Arabia

CITATION: Antunes A (2020) Out of This World: From the Bottom of the Red Sea to the Red Planet. Front. Young Minds 8:545761. doi: 10.3389/frym.2020.545761

CONFLICT OF INTEREST: The author declares that the research was conducted in the absence of any commercial or financial relationships that could be construed as a potential conflict of interest.

COPYRIGHT () 2020 Antunes. This is an open-access article distributed under the terms of the Creative Commons Attribution License (CC BY). The use, distribution or reproduction in other forums is permitted, provided the original author(s) and the copyright owner(s) are credited and that the original publication in this journal is cited, in accordance with accepted academic practice. No use, distribution or reproduction is permitted which does not comply with these terms.

\section{YOUNG REVIEWERS}

\section{CHLOE, AGE: 15}

Hello! My name is Chloe, I am currently 15 years old. My hobbies include reading, singing, writing, and researching. I love to spend hours reading online or with paperback, depending on my mood, I just love to read. I am currently living with my two Persian cats that love to sing in the night like me and are both lazy like me. In the future, I would like to be a virologist or a genetic scientist, if I do not get to be one of them, I am just gonna be an author...

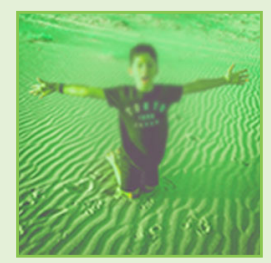

\section{FABIÁN, AGE: 12}

Fabián is a world traveling, 12 years old, seventh grade polyglot who loves the ocean and being creative. His hobbies are: mountain biking, lego, inventing, acting, and reading, but especially reading. He loves being a part of the Frontiers for Young Minds program and looks forward to next year! 

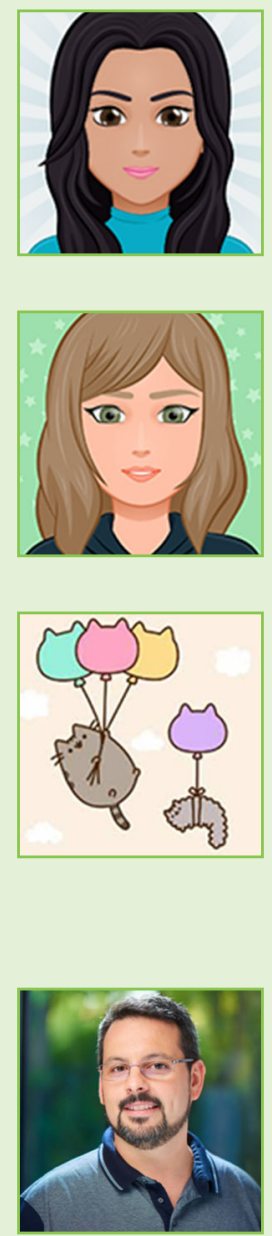

\section{NAGA, AGE: 15}

I am a 15 year old girl, only child, born and raised in India. I have been living in KAUST for 7 years. I love to sing and dance, and perform any kind of sports. I like theater, but not enough to perform live because I always forget my lines

\section{SAGE, AGE: 11}

I am Sage, I like drawing, art, and playing my violin. I write stories and read my fave books like Septimus Heap and Harry Potter. I am creative and like adventures, I like customizing clothes and making bracelets and I am a good singer.

\section{XENIA, AGE: 15}

My name is Xenia. I like Science and I think it is awesome to be able to read a scientific article and actually understand what it says. In my spare time I like to read, do gymnastics, and take pictures.

\section{AUTHOR}

\section{ANDRÉ ANTUNES}

I am an Associate Professor and leader of the Astrobiology Unit of the State Key Laboratory of Lunar and Planetary Science at the Macau University of Science and (Macau, China). I study life on the edge and exotic new microbes living in unexplored extreme environments, from salty lakes, to mines, to deep-sea locations. Many of these environments have conditions similar to those found on Mars and other planets. Studying these environments helps us when looking for life outside our planet and allows us to find the limits of life. Extreme environments are a source of unusual new species and new applications that can help us to feed, fuel, and heal the world. *aglantunes@must.edu.mo 